\title{
ASPEK BIOLOGI IKAN PARI BLENTIK (Dasyatis cf. kuhlii) YANG TERTANGKAP DI LAUT JAWA
}

\author{
Dharmadi ${ }^{1}$ \\ 1) Peneliti pada Pusat Riset Perikanan Tangkap, Ancol-Jakarta \\ Teregristrasi I tanggal: 15 Mei 2008; Diterima setelah perbaikan tanggal: 13 Oktober 2008; \\ Disetujui terbit tanggal: 23 Oktober 2008
}

\begin{abstract}
ABSTRAK
Penelitian dilakukan pada tahun 2002 sampai dengan 2003 di tempat pendaratan ikan Muara Angke dan Laboratorium Balai Riset Perikanan Laut Muara Baru, Jakarta. Data aspek biologi reproduksi ikan pari blentik (Dasyatis cf. kuhlii), berasal dari hasil tangkapan sampingan dari alat tangkap jaring dasar yang beroperasi di Laut Jawa dan didaratkan di tempat pendaratan ikan Muara Angke. Hasil penelitian menunjukkan ukuran lebar tubuh ikan pari blentik (Dasyatis cf. kuhlii) terkecil antara 170 sampai dengan $190 \mathrm{~mm}$ dan ukuran terbesar antara 330 sampai dengan $350 \mathrm{~mm}$. Hubungan antara lebar cawan dan panjang klasper ikan pari blentik (Dasyatis cf. kuhlii) menunjukan hubungan yang linier $\left(R^{2}=0,7629\right)$. Kondisi klasper belum terjadi pengapuran atau sebagian mengandung zat kapur (non or partially calcified claspers) terdapat pada ukuran lebar tubuh <200 $\mathrm{mm}$, sedangkan kondisi klasper penuh zat kapur (fully calcified claspers) terdapat pada ukuran lebar tubuh $>250 \mathrm{~mm}$. Ukuran embrio terkecil dijumpai pada bulan Januari yaitu antara 25 sampai dengan $30 \mathrm{~mm}$ dan terbesar antara 110 sampai dengan 115 pada bulan Agustus. Sebagian besar ikan pari blentik (Dasyatis cf. kuhlii) jantan yang tertangkap di Laut Jawa dalam kondisi matang kelamin. Berdasarkan pada uji $X^{2}$, perbandingan kelamin jantan dan betina berbeda nyata $(P<0,1)$.
\end{abstract}

KATAKUNCI: aspek biologi, pari blentik, Laut Jawa

ABSTRACT: Biological aspects of blue spotted stingray (Dasyatis cf. kuhlii) caught in the Java Sea. By: Dharmadi

This study was conducted at Muara Angke fish landing site and Research Institute for Marine Fisheries Laboratory Muara Baru Jakarta on 2002 to 2003. Reproduction biology data of Dasyatis cf. kuhlii were taken from catched of bottom net fishing gear that operated in the Java Sea. The result showed that the smallest and the biggest of Dasyatis cf. kuhlii ranging from 170 to $190 \mathrm{~mm}$ and 330 to $350 \mathrm{~mm}$ disc width, respectively. Relationship between clasper length and disc width was linier $\left(R^{2}=0.7629\right)$. Condition of sex maturity stage of male was non or partially calcified claspers found at size $<200 \mathrm{~mm} \mathrm{Wd}$, while fully calcified claspers was found at size $>250 \mathrm{~mm} W d$. The smallest size embryo of ranging from 25 to $30 \mathrm{~mm}$ was found in January and the biggest ranging from 110 to 115 $\mathrm{mm}$ was found from in August. Most of Dasyatis cf. kuhlii caught in the Java Sea were mature. Sex ratio was significant different between male and female ( $X^{2}$ test, $\left.P<0.1\right)$.

\section{KEYWORDS: $\quad$ biological aspect, blue spotted stingray, Java Sea}

\section{PENDAHULUAN}

Perikanan Elasmobranchiidi Indonesia merupakan perikanan yang terbesar di dunia. Hasil tangkapan yang didaratkan pada tahun 2002 dan 2003 masingmasing 105.000 ton dan 118.000 ton (Anonym, 2002; 2003). Bahkan menurut catatan FAO dalam Lack \& Sant (2006) hasil tangkapan ikan cucut (Requiem shark sp.) dan pari (Plesiobatis sp.) secara global mencapai puncak pada tahun 2003 yaitu 880.000 ton, atau $17 \%$ lebih tinggi dibanding hasil tangkapan tahun 2004 yaitu 810.000 ton. Dikatakan bahwa dalam kurun waktu 15 tahun Indonesia menduduki rangking tertinggi dari 20 negara dalam hal eksploitasi sumber daya ikan cucut (Requiem shark sp.) dan pari (Plesiobatis sp.) yang tercatat 122.000 ton selama tahun 1990 sampai dengan 2004 atau 12,3\% dari data hasil tangkapan total dari 20 negara. Sedangkan produksi ikan cucut (Requiem shark sp.) dan pari (Plesiobatis sp.) tahun 2005 adalah 100.037 ton (Direktorat Jenderal Perikanan Tangkap, 2007).

Proporsi kelompok ikan pari (Plesiobatis sp.) dari seluruh ikan-ikan bertulang rawan yang didaratkan meningkat tajam dari 32\% pada tahun 1981 menjadi $51 \%$ dalam tahun 2003 (Anonym, 2003). Meskipun terjadi peningkatan hasil tangkapan dan upaya penangkapan untuk Elasmobranchii, namun hasil tangkapan per upaya (catch per unit of effort) menurun (Monintja \& Poernomo, unpubl. data), dan kemungkinan terjadi penurunan terhadap kelimpahan. Kendatipun Indonesia memiliki sumber daya ikan-ikan bertulang rawan terkaya di dunia (Last \& Stevens, 1994; Carpenter \& Niem, 1998; 1999), tetapi informasi

Kosrespondensi penulis: 
tentang aspek biologi reproduksi relatif sedikit. Kelompok ikan pari (Plesiobatis sp.) yang termasuk dalam famili Dasyatidae yang paling sering tertangkap dalam jumlah berlimpah di perairan dekat pantai di daerah tropis di seluruh dunia dan memiliki peranan penting pada perikanan artisanal maupun komersial (Carpenter \& Niem, 1999). Salah satu spesies yang termasuk dalam famili Dasyatidae Dasyatis kuhliiatau dikenal oleh nelayan di Jawa Tengah dengan sebutan ikan pari blentik atau pari kodok (Jakarta). Ikan pari (Plesiobatis sp.) ini merupakan ikan demersal yang sering tertangkap di perairan dangkal dan paparan benua pada kedalaman sampai dengan $90 \mathrm{~m}$. Secara morfologi, spesies ini mempunyai ciri yang mudah dibedakan dengan jenis ikan pari (Plesiobatis sp.) lain yang dalam 1 genus pada tubuh terdapat bintikbintik warna biru cerah sehingga dinamakan bluespotted stingray. Dalam status konservasi, oleh IUCN salah satu badan internasional yang sangat peduli terhadap sumber daya Elasmobranchii, spesies ini termasuk kelompok yang belum dievaluasi dalam daftar merah red list (White et al., 2006), sehingga sampai dengan saat ini dianggap aman untuk dieksploitasi tetapi tetap mempertimbangkan kelestarian. Karena kelompok ikan Elasmobranchii memiliki pertumbuhan dan kematangan kelamin lambat, reproduksi rendah dan berumur panjang, sehingga rentan terhadap kepunahan apabila dieksploitasi tanpa terkendali. Namun demikian, penelitian aspek reproduksi ikan-ikan bertulang rawan perlu dilakukan sebagai bahan pertimbangan dalam menentukan status konservasi pada perikanan Elasmobranchii. Beberapa penelitian tentang biologi reproduksi dari beberapa spesies genus Dasyatis telah dilakukan oleh Snelson et al., 1988; 1989; Capape, 1993; Johnson \& Snelson, 1996). Meskipun data biologi dari ikan pari (Batoidea) kurang, tetapi di perairan di seluruh dunia dan sebagian Asia Tenggara, kelompok ikan-ikan bertulang rawan baik yang tertangkap sebagai sasaran utama maupun tangkapan sampingan eksploitasi relatif tinggi (White \& Dharmadi, 2007). Ikan pari blentik (Dasyatis cf. kuhlii) berkembang biak dengan ovoviviparous yaitu bertelur dan embrio berkembang di dalam tubuh individu betina dan mendapat makanan yang tersedia dalam kantong telur (Anonym, 2006a). Tulisan ini menyajikan tentang aspek biologi reproduksi yang meliputi frekuensi ukuran lebar cawan, hubungan lebar cawan dengan panjang klasper, tingkat kematangan kelamin dan ukuran embrio berdasarkan pada waktu dan nisbah kelamin dari ikan pari blentik (Dasyatis cf. kuhlii) yang tertangkap di Laut Jawa.

\section{BAHAN DAN METODE}

Pengambilan contoh biologi ikan pari blentik (Dasyatis cf. kuhlii) dilakukan dalam tahun 2002 sampai dengan 2003 di tempat pendaratan ikan Muara Angke secara acak dari hasil tangkapan jaring dasar (trammel net) yang beroperasi di Laut Jawa. Contoh diperoleh setelah proses pembongkaran ikan di palka kapal selesai atau sebelum diangkut ke pasar atau tempat pelelangan ikan Muara Angke, kemudian diberi es, dan dengan menggunakan cold box sampel diangkut ke Laboratorium Biologi Balai Riset Perikanan Laut Muara Baru untuk diproses. Tingkat kematangan gonad pada betina dicatat dengan kriteria belum matang, matang tetapi belum bunting, atau matang dalam keadaan bunting. Pengukuran diameter telur sampai dengan dalam satuan $0,1 \mathrm{~mm}$ dan dilakukan pencatatan jenis kelamin embrio. Pengukuran data biologi meliputi lebar cawan, diameter telur, pengamatan jenis kelamin dan tingkat kematangan jantan, dan kematangan gonad mengacu pada Martin \& Coillet dalam White et al. (2001) seperti pada Lampiran 1. Lebar cawan diukur menggunakan alat pengukur dengan ketelitian $1 \mathrm{~mm}$. Pengukuran alat kelamin jantan (klasper) mulai bagian dalam sirip perut sampai dengan ujung klasper dalam satuan $\mathrm{mm}$ dengan kategori klasper dalam kondisi penuh zat kapur (full calcification), sebagian mengandung zat kapur (partially calcification) dan tanpa zat kapur (non calcified). Analisis data untuk mengetahui korelasi antara 2 parameter yang diukur dilakukan dengan menggunakan statistik regresi berdasarkan pada software minitab release 13. Rumus persamaan regresi yang digunakan (persamaan linier, $y=73.141 \mathrm{Ln}(\mathrm{x})-371.07)$. Jumlah ikan pari (Plesiobatis sp.) jantan dan betina dicatat dan dianalisis berdasarkan pada uji $x^{2}$ untuk menentukan apakah nisbah kelamin terdapat perbedaan yang nyata atau tidak (Clark, 1993).

\section{HASIL DAN BAHASAN}

\section{Frekuensi Lebar Tubuh}

Frekuensi lebar tubuh ikan pari blentik (Dasyatis cf. kuhlii) jantan dan betina disajikan pada Gambar 1. Frekuensi lebar tubuh tertinggi baik jantan maupun betina terdapat pada kelas ukuran antara 240 sampai dengan $260 \mathrm{~mm}$ dan terendah pada kelas ukuran antara 300 sampai dengan $310 \mathrm{~mm}$ dan 350 sampai dengan $360 \mathrm{~mm}$ pada jantan dan 170 sampai dengan $180 \mathrm{~mm}$ dan lebih dari $350 \mathrm{~mm}$ pada betina. Dari 
gambar tersebut nampak bahwa paling tidak terdapat 4 kelompok umur pada ikan pari blentik (Dasyatis cf. kuhlii) jantan dan betina yaitu kelompok umur pertama terdapat pada kelas ukuran antara 170 sampai dengan $220 \mathrm{~mm}$, kelompok umur ke-2 pada kelas ukuran antara 230 sampai dengan $270 \mathrm{~mm}$, kelompok umur ke-3 pada kelas ukuran antara 280 sampai dengan $310 \mathrm{~mm}$ dan pada kelompok umur ke-4 terdapat pada kelas ukuran antara 320 sampai dengan $350 \mathrm{~mm}$. Dapat dikatakan bahwa hampir setiap kelompok umur terjadi tumpang-tindih antara jantan dan betina pada pola pertumbuhan. Ikan pari blentik (Dasyatis cf. kuhlii) dari Laut Jawa berukuran lebar tubuh (LT) mencapai $380 \mathrm{~mm}$, pari jantan dewasa pada ukuran
220 sampai dengan $230 \mathrm{~mm}$ LT, ukuran ketika lahir 110 sampai dengan $160 \mathrm{~mm}$. Jenis ikan pari blentik (Dasyatis cf. kuhlii) dari Samudera Hindia yang didaratkan di Bali dapat mencapai ukuran $450 \mathrm{~mm}$ LB, pari jantan dewasa berukuran 310 sampai dengan $320 \mathrm{~mm}$ dan ukuran ketika lahir $170 \mathrm{~mm}$ (White et al., 2006). Dasyatis cf. kuhlii dapat mencapai ukuran lebar tubuh $400 \mathrm{~mm}$ dan panjang total 700 sampai dengan $750 \mathrm{~mm}$, tetapi jantan yang matang kelamin terdapat pada ukuran lebar tubuh 250 mm (Anonym, 2006a). Di perairan Australia ukuran lebar tubuh spesies ini pada saat kira-kira $160 \mathrm{~mm}$ dan dapat mencapai lebar maksimum sekitar $380 \mathrm{~mm}$ (Last \& Stevens, 1994).

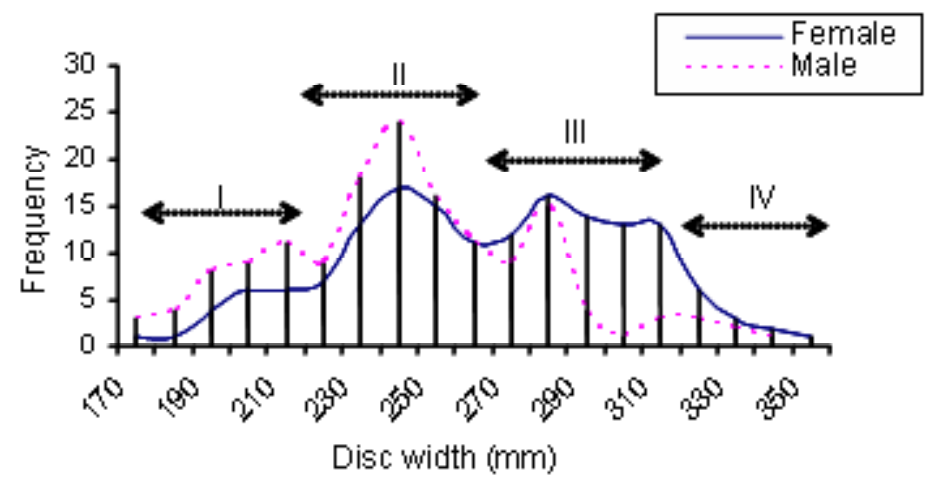

Gambar 1. Frekuensi lebar tubuh pari blentik (Dasyatis cf. kuhlii). Figure 1. Disc width frequency of Dasyatis cf. kuhlii.

Ukuran lebar cawan ikan pari blentik (Dasyatis cf. kuhlii) dari hasil penelitian ini $350 \mathrm{~mm}$, sedangkan hasil penelitian White et al. (2006) berdasarkan pada hasil pengambilan contoh di tempat pendaratan ikan Pekalongan diperoleh ukuran lebar tubuh terbesar 380 $\mathrm{mm}$, sehingga dapat dikatakan bahwa ukuran terbesar ikan pari blentik (Dasyatis cf. kuhlii) yang tertangkap di Laut Jawa antara 350 sampai dengan $380 \mathrm{~mm}$. Ukuran ini lebih kecil bila dibandingkan dengan spesies yang sama yang tertangkap di perairan Samudera Hindia yang didaratkan di tempat pendaratan ikan Kedonganan, Bali yang berukuran lebar tubuh antara 300 sampai dengan $450 \mathrm{~mm}$ (White \& Dharmadi, 2007). Perbedaan ukuran ini diduga karena perbedaan kondisi lingkungan perairan antara di Laut Jawa dan Samudera Hindia. Perbedaan ukuran pada spesies yang sama dan daerah penangkapan berbeda, menurut Parsons; Lombardi-Carlson et al. dalam Motta et al. (2005) dapat disebabkan oleh perbedaan kondisi oseanografi sehingga dapat menyebabkan terjadi perbedaan parameter biologi antara populasi misal ukuran maksimum, tingkat pertumbuhan, ukuran matang kelamin, dan matang gonad. Sedangkan Thorson (1983) menduga bahwa terjadi perbedaan ukuran suatu spesies karena ada perbedaan karakteristik populasi.

\section{Hubungan Lebar Cawan dan Panjang Klasper}

Keterkaitan antara ukuran panjang atau lebar badan dengan ukuran perkembangan alat kelamin atau gonad suatu spesies bertujuan untuk menentukan ukuran pertama kali matang kelamin atau gonad dan mengetahui musim pemijahan. Hubungan antara panjang klasper dan perkembangan ukuran tubuh merupakan parameter yang umum digunakan untuk mengetahui tingkat kematangan kelamin jantan pada Elasmobranchii (Castro et al., 1988; Capapé et al., 1990; Stevens \& McLoughlin, 1991). Walaupun ke-2 klasper yang tumbuh pada ikan pari (Plesiobatis sp.) dapat berfungsi dalam kopulasi, tetapi hanya 1 yang dimasukan dalam kloaka betina selama proses perkawinan (White, 2003). Hasil penelitian ini memperlihatkan hubungan antara lebar cawan dan panjang klasper ikan pari blentik (Dasyatis cf. kuhlii) cenderung linier $\left(\mathrm{R}^{2}=0,7629\right)$ (Gambar 2) artinya perkembangan ukuran klasper diikuti dengan pertambahan ukuran lebar tubuh. Dari hasil pengamatan diketahui bahwa ikan pari blentik (Dasyatis cf. kuhlii) jantan yang berukuran kurang dari $200 \mathrm{~mm}$, klasper dalam kondisi belum terjadi pengapuran atau sebagian mengandung zat kapur ( $n o n$ or partially calcified claspers), sedangkan semua 
jantan yang berukuran lebih dari $250 \mathrm{~mm}$, klasper dalam kondisi penuh zat kapur (fully calcified claspers). Dengan demikian, sebagian besar ikan pari blentik (Dasyatis cf. kuhlii) jantan yang tertangkap di Laut Jawa dalam kondisi matang kelamin. Sedangkan pada ikan pari blentik (Dasyatis cf. kuhlii) betina matang gonad tidak terdapat perbedaan nilai tengah pada pengamatan bulanan dengan kisaran antara 6 sampai dengan $11 \mathrm{~mm}$ (Gambar 3). Besar kisaran nilai tengah tiap bulan, menunjukkan bahwa perkembangan oocyte spesies ini tidak bersifat musiman atau perkembangan oocyte dapat terjadi setiap bulan.

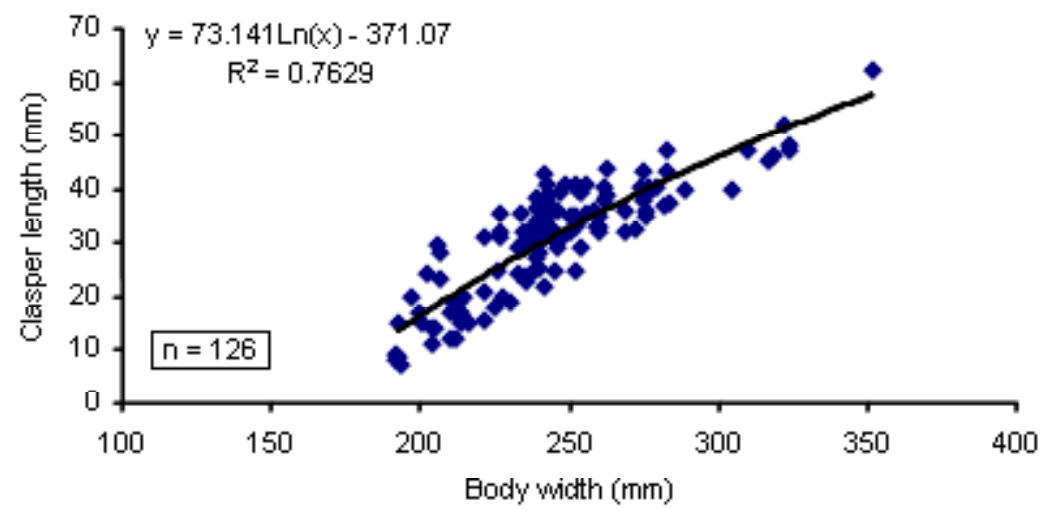

Gambar 2. Hubungan antara lebar tubuh dan panjang klasper pari blentik (Dasyatis cf. kuhlii). Figure 2. Relationship between disc width and clasfer length of Dasyatis cf. kuhlii.

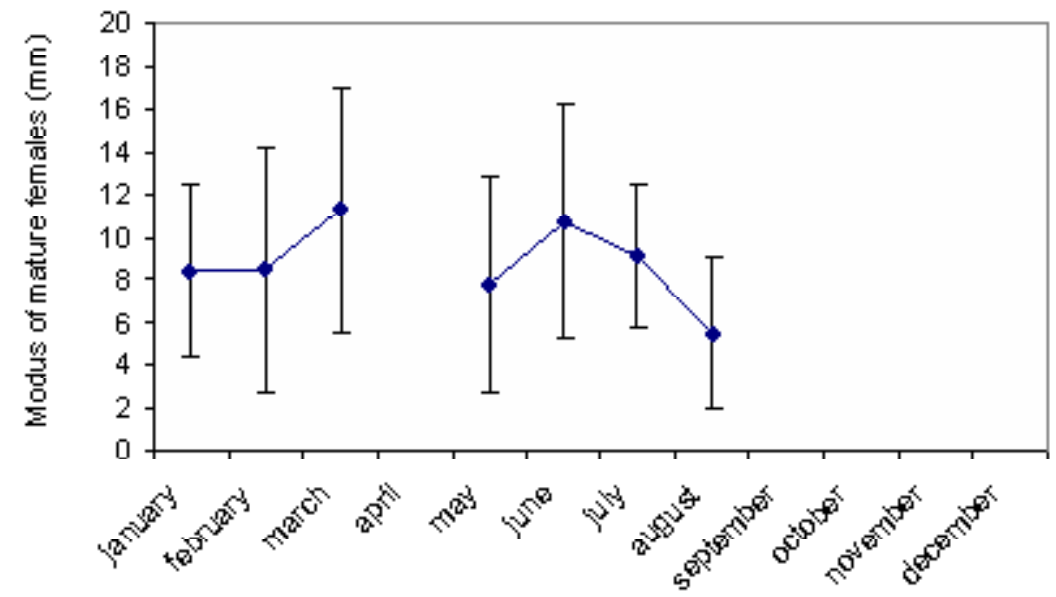

Gambar 3. Hubungan antara waktu dan nilai tengah ikan pari blentik (Dasyatis cf. kuhlii) matang gonad. Figure 3. Relationship between time and modus of Dasyatis cf. kuhlii gonad mature.

\section{Hubungan antara Waktu dan Perkembangan Embrio}

Dari 119 jumlah contoh dalam kondisi matang kelamin pada betina $60 \%$ dalam keadaan bunting. Jumlah embrio tercatat 36 ekor memiliki perkembangan ukuran yang bervariasi berdasarkan pada waktu (Gambar 4) dan cenderung ukuran embrio meningkat dengan bertambah waktu. Dari jumlah embrio tersebut terdiri atas $57 \%$ jantan dan 43 betina. Ukuran embrio terkecil dijumpai pada bulan Januari antara 25 sampai dengan $30 \mathrm{~mm}$ dan terbesar antara 110 sampai dengan 115 pada bulan Agustus. Bulan April, September, sampai dengan Desember tidak ditemukan embrio dalam contoh. Dengan ditemukan embrio dalam contoh pada hampir setiap bulan, maka dapat dikatakan bahwa reproduksi ikan pari blentik (Dasyatis cf. kuhlii) diduga tidak bersifat musiman. Meskipun demikian, diperlukan data yang runtun waktu untuk mengetahui secara pasti musim dan perkembangan reproduksi.

\section{Tingkat Kematangan Kelamin}

Frekuensi tingkat kematangan kelamin jantan ikan pari blentik (Dasyatis cf. kuhlii) disajikan pada Gambar $5 a$ dan b. Berdasarkan pada gambar tersebut dapat dilihat bahwa baik jantan dan betina masing-masing terdapat 5 tingkat kematangan kelamin dan gonad. 
Sedangkan perkembangan tingkat kematangan kelamin jantan dan betina disajikan pada Lampiran 1.

Frekensi tingkat kematangan kelamin baik jantan dan betina ikan pari blentik (Dasyatis cf. kuhlii) memperlihatkan pola perkembangan tingkat kematangan yang sama. Frekuensi tingkat kematangan meningkat dari tingkat I ke tingkat III lalu menurun pada tingkat IV dan V. Dari gambar tersebut nampak bahwa frekuensi tertinggi tingkat kematangan kelamin baik jantan dan betina terdapat pada tingkat III (matang), sehingga sebagian besar ikan pari blentik (Dasyatis cf. kuhlii) yang tertangkap merupakan ikan pari (Plesiobatis sp.) dalam kondisi matang kelamin dan matang gonad.

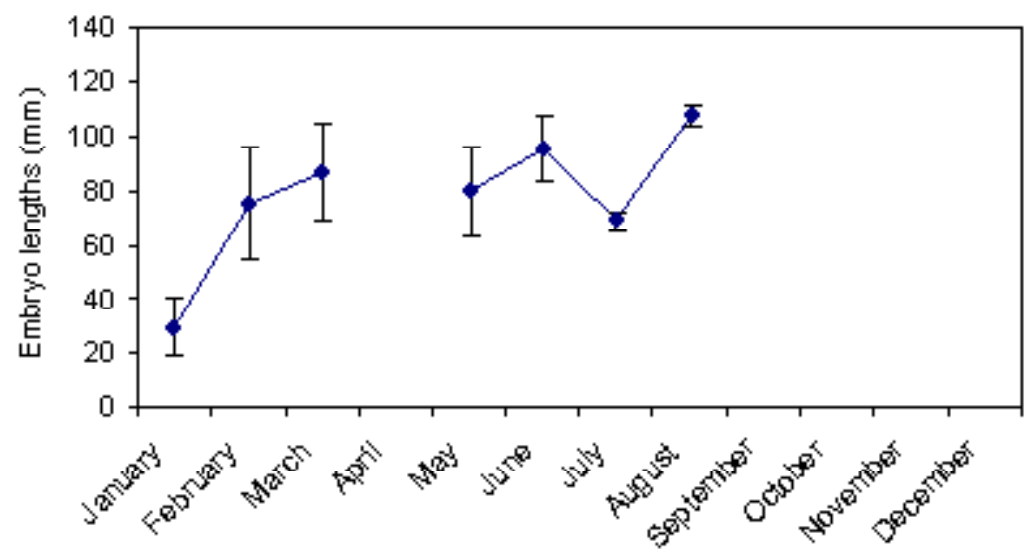

Gambar 4. Hubungan antara waktu dan ukuran embrio ikan pari blentik (Dasyatis cf. kuhlii). Figure 4. Relationship between time and embryo size of Dasyatis cf. kuhlii.

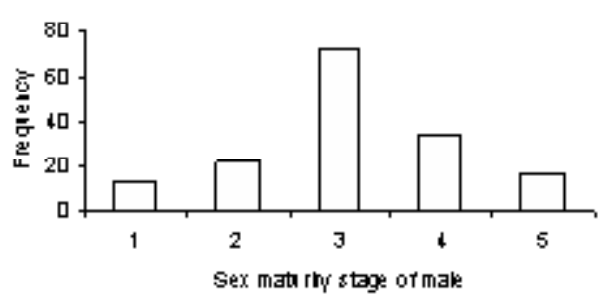

(a)

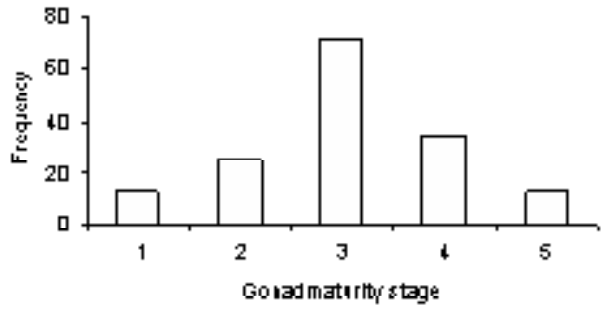

(b)

Gambar 5. Histogram frekuensi tingkat kematangan kelamin jantan (a) dan betina (b) ikan pari blentik (Dasyatis cf. kuhlii).

Figure 5. $\quad$ Frequency histogram maturity stage of male and female of Dasyatis cf. kuhlii.

\section{Nisbah Kelamin}

Dalam proses rekruitmen spesies dalam suatu populasi, kemampuan individu spesies ditunjukkan dengan perbandingan kelamin (nisbah kelamin) (Anonym, 2006b). Dalam perairan yang normal, ideal perbandingan kelamin jantan dan betina 1:1.

Perbandingan jenis kelamin jantan dan betina ikan pari blentik (Dasyatis cf. kuhlii) 44:56\% $(0,7: 1,3)$, berdasarkan pada uji $X^{2}$, perbandingan tersebut berbeda nyata $(P<0,01)$ (Gambar 6). Hasil perbandingan jenis kelamin pada ikan pari blentik (Dasyatis cf. kuhlii) yang tertangkap di Laut Jawa dari penelitian ini dapat dikatakan bahwa perbandingan tersebut tidak seimbang, karena sebagian besar ikan pari blentik (Dasyatis cf. kuhlii) yang tertangkap betina. Sementara itu, ikan pari (Plesiobatis sp.) betina yang tertangkap frekuensi tingkat kematangan gonad tertinggi tingkat III (Gambar $5 \mathrm{~b}$ ) yang termasuk dalam kategori matang, sehingga akan mempengaruhi kesimbangan populasi. Walaupun status populasi spesies ini belum tergolong lebih tangkap karena dianggap sebagai hasil tangkapan sampingan, tetapi secara umum sumber daya ikan di Laut Jawa sudah dianggap overeksploitasi, maka hal ini perlu mendapat perhatian bersama. Meskipun demikian, menurut Dudley \& Simpfendorfer (2006) 1 stok populasi 
dikatakan mengalami over eksploitasi (over fishing) apabila terjadi penurunan yang signifikan terhadap ukuran rata-rata ikan yang tertangkap. Perbedaan perbandingan jenis kelamin kemungkinan merupakan hasil pemisahan kelamin yang umum terjadi pada kelompok ikan-ikan bertulang rawan (Springer, 1967). Perbedaan teknik penangkapan dan selektivitas alat tangkap dapat juga mempengaruhi perbedaan perbandingan jenis kelamin pada spesies ikan yang tertangkap.

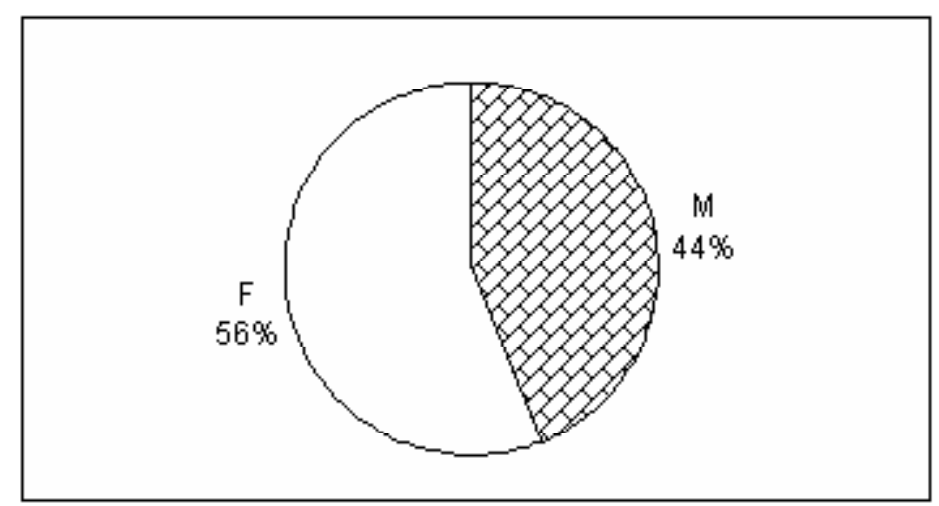

Gambar 6. Nisbah kelamin ikan pari blentik (Dasyatis cf. kuhlii).

Figure 6. Sex ratio of Dasyatis cf. kuhlii.

\section{KESIMPULAN}

Frekuensi lebar tubuh tertinggi baik jantan maupun betina terdapat pada kelas ukuran antara 240 sampai dengan $260 \mathrm{~mm}$ dan terendah pada kelas ukuran antara 300 sampai dengan $310 \mathrm{~mm}$ dan 350 sampai dengan $360 \mathrm{~mm}$ pada jantan dan 170 sampai dengan $180 \mathrm{~mm}$ dan lebih dari $350 \mathrm{~mm}$ pada betina. Paling tidak terdapat 4 kelompok umur pada ikan pari blentik (Dasyatis cf. kuhlii) jantan dan betina yaitu masingmasing berukuran antara 170 sampai dengan $220 \mathrm{~mm}$, 230 sampai dengan $270 \mathrm{~mm}, 280$ sampai dengan 310 $\mathrm{mm}$, dan 320 sampai dengan $350 \mathrm{~mm}$. Kondisi belum terjadi pengapuran atau sebagian mengandung zat kapur (non or partially calcified claspers) terdapat pada ukuran $<200 \mathrm{~mm}$, sedangkan ukuran panjang klasper $>250 \mathrm{~mm}$, dalam kondisi penuh zat kapur (fully calcified claspers). Sebagian besar dari jumlah contoh baik jantan dan betina dalam kondisi matang. Perbandingan jenis kelamin jantan dan betina ikan pari blentik (Dasyatis cf. kuhlii) berbeda nyata $(P<0,01)$.

\section{PERSANTUNAN}

Kegiatan dari hasil riset perikanan artisanal ikan cucut (Requiem shark sp.) dan pari (Plesiobatis sp.) di perairan Indonesia Timur: Sosial ekonomi dan karakteristik perikanan hubungannya dengan sumber daya perikanan di perairan Australia, T.A. 2001-2006, ACIAR-CSIRO Australia.

\section{DAFTAR PUSTAKA}

Anonym. 2002. Statistics of marine capture fisheries production by Fishery Managed Areas. Jakarta. Ministry of Marine Affairs and Fisheries.

Anonym. 2003. Statistics of marine capture fisheries production by Fishery Managed Areas. Jakarta: Ministry of Marine Affairs and Fisheries.

Anonym. 2006a. Find a fish blue spotted stingray Dasyatis kuhlii (Muller \& Henle, 1841). Australian Museum Fish Site.

Anonym. 2006b. Male biased sex ratio of fish embryos near a pulp mill: Temporary recovery after a shout term shutdown (Research Article).

Almeida, P. C., M. L. Araújo, \& M. P. Almeida. 2005. Reproductive aspects of freshwater stingrays (Chondrichthyes: Potamotrygonidae) in the Brazilian Amazon Basin. Journal Northw. Atl. Fishery Science. Vol.35. 165-171.

Capapé, C., J. P. Quignard, \& J. Mellinger. 1990. Reproduction and development of two angel sharks, Squatina squatina and Squatina oculata (Pisces: Squatinidae), off Tunisian coasts: semi delayed vitellogenesis, lack of egg capsules, and lecithotrophy. Journal of Fishery Biology. 37: 347356. 
Capape, C. 1993. New data on the reproductive biology of the thorny stingray, Dasyatis centroura (Pisces: Dasyatidae) from off the Tunisian coasts. Environmental Biology of Fishes. 38. 73-80.

Clarke, K. R. 1993. Non parametric multivariate analysis of changes in community structure. Australian Journal of Ecology. 18. 117-143.

Carpenter, K. E. 1998. An Introduction to the oceanography, geology, biogeography, and fisheries of the tropical and subtropical western and Central Pacific. In FAO Species Identification Guide for Fishery Purposes. The Living Marine Resources of the Western Central Pacific. Vol.1. Seaweeds, Corals, Bivalves, and Gastropods. p. 1-686. K. E. Carpenter \& V. H. Niem (eds). FAO. Rome.

Carpenter, K. E. \& V. H. Niem (eds). 1999. FAO Species identification guide for fishery purposes. The Living Marine Resources of the Western Central Pacific. Vol.3. Batoid Fishes, Chimaeras and Bony Fishes. Part 1 (Elopidae to Linophyrnidae). p. 1.397-2.068. FAO. Rome.

Direktorat Jenderal Perikanan Tangkap. 2007. Data statistik perikanan. Departemen Kelautan dan Perikanan. 279 hal.

Dudley, S. F. J. \& Simpfendorfer, C. A. 2006. Population status of 14 shark species caught in the protective gill nets off Kwa Zulu-Natal beaches. South Africa. 1978-2003. Marine and Freshwater Research. 57. 225-240.

Johnson, M. R. \& Snelson, F. F. Jr. 1996. Reproductive life history of the Atlantic stingray, Dasyatis sabina (Pisces, Dasyatidae), in the freshwater St. Johns River, Florida. Bulletin of Marine Science. 59. 7488.

Lack, M. \& G. Sant. 2006. Confronting shark conservation head on! Published by traffic international, Cambridge, U. K. Traffic International.

Last, P. R. \& Stevens, J. D. 1994 Sharks and rays of Australia. CSIRO Division of Fisheries. Hobart Australia. p. 513.

Motta, F. S., O. B. F. Gadig, R. C. Namora, \& F. M. S. Braga. 2005. Size and sex compositions, length weight relationship, and occurrence of the Brazilian sharpnose shark, Rhizoprionodon lalandii, caught by artisanal fishery from southeastern Brazil. Fisheries Research. 74 (2005). 116-126.
Snelson, F. F. Jr, S. E. Williams-Hooper, \& T. H. Schmid. 1988. Reproduction and ecology of the Atlantic stingray, Dasyatis sabina, in Florida coastal lagoons.

Snelson, F. F. Jr, S. E. Williams-Hooper, \& Schmid, T. H. 1989. Biology of the bluntnose stingray, Dasyatis sayi, in Florida coastal lagoons. Bulletin of Marine Science. 45. 15-25.

Springer, S. 1967. Social organisations of shark populations. In Sharks, Skates, and Rays (Gilbert, P. W., R. F. Mathewson, \& D. P. Rall, eds). pp. 149-173. Baltimore. MD. Johns Hopkins Press.

Stevens, J. D. \& K. J. McLoughlin. 1991. Distribution, size, and sex composition, reproductive biology and diet of sharks from northern Australia. Australian Journal of Marine and Freshwater Research. 42. 151-199.

Thorson, T. B. 1983. Observations on the morphology, ecology, and life history of the euryhaline stingray, Dasyatis guttata (Bloch and Schneider) 1801. Acta Biologica Venezuelica. 11. 95-125.

White, W. T. 2003. Aspects of the biology of Elasmobranchs in a subtropical embayment in Western Australia and of chondrichthyan fisheries in Indonesia. Thesis of Doctor of Philosophy at Murdoch University. Western Australia. 212 p.

White, W. T., Platell, M. E., \& Potter, I. C. 2001. Relationship between reproductive biology and age composition and growth in Urolophus lobatus (Batoidea: Urolophidae). Marine Biology. 138. 135147.

White, W. T. \& Dharmadi. 2007. Species, size compositions, and reproductive biology of rays (Chondrichthyes, Batoidea) caught in target and non target fisheries in eastern Indonesia. The Fisheries Society of the British Isles. Journal of Fishery Biology. 2007 70. 1.809-1.837.

White, W. T., J. Giles, Dharmadi, \& I. C. Potter. 2006. Data on the bycatch fishery and reproductive biology of mobulid rays (Myliobatiformes) in Indonesia. Fisheries Research. 82. 65-73.

White, W. T., P. R. Last, J. D. Stevens, Y G. Kearsley, Fahmi, \& Dharmadi. 2006. Economically important sharks and rays of Indonesia. Canberra. ACIAR Publishing. 329 p. 
Lampiran 1. Tingkat kematangan pada ikan bertulang rawan Appendix 1. Maturity stage of Elasmobranchii

\begin{tabular}{|c|c|c|}
\hline No. & $\begin{array}{l}\text { Tingkat kematangan/ } \\
\text { Maturity stage }\end{array}$ & $\begin{array}{c}\text { Perkembangan secara mikroskopis/ } \\
\text { Microcopies developing }\end{array}$ \\
\hline & Betina & \\
\hline 1. & Belum matang & Ovari dan testis kecil, ke-2 uteri berukuran sama, tipis, dan lunak. \\
\hline 2. & Berkembang, anak dara & $\begin{array}{l}\text { Ovari bagian kiri berisi kantong telur berukuran kecil, uterus bagian kiri } \\
\text { mulai membesar tetapi tipis dan lunak. }\end{array}$ \\
\hline 3. & Matang, belum bunting & $\begin{array}{l}\text { Ovari bagian kiri berisi telur berdiameter }>2 \mathrm{~mm} \text {, lunak, dan tipis. Uterus } \\
\text { bagian kiri banyak mengandung trophonemata. }\end{array}$ \\
\hline 4. & Matang, bunting & $\begin{array}{l}\text { Ovari bagian kiri berdiameter }>2 \mathrm{~mm} \text {. Terjadi pembuahan telur atau } \\
\text { embrio pada uterus bagian kiri. Trophonemata membesar dan berwarna } \\
\text { gelap. }\end{array}$ \\
\hline \multirow[t]{2}{*}{5.} & Matang, pulih salin & $\begin{array}{l}\text { Ovari bagian kiri berdiameter }>2 \mathrm{~mm} \text {. Uterus bagian kiri membesar tetapi } \\
\text { lunak, terlihat baru melahirkan anak. Trophonemata berwarna gelap. }\end{array}$ \\
\hline & Jantan & \\
\hline 1. & Belum matang & $\begin{array}{l}\text { Testis belum berkembang, klasper berukuran kecil, dan belum terjadi } \\
\text { pengapuran. }\end{array}$ \\
\hline 2. & Sedang berkembang & $\begin{array}{l}\text { Testis membesar tapi tanpa lubang-lubang di permukaan, vas deferens } \\
\text { (saluran sperma) membulat. Klasper membesar, mulai terjadi pengapuran } \\
\text { dan kaku. }\end{array}$ \\
\hline 3. & Matang, belum bereproduksi & $\begin{array}{l}\text { Lubang-lubang pada testis membengkak disebabkan memproduksi } \\
\text { sperma. Saluran sperma membulat kencang. Klasper sangat berkembang } \\
\text { dan kaku disebabkan oleh zat kapur. }\end{array}$ \\
\hline 4. & Matang & $\begin{array}{l}\text { Seminal vesikel penuh spermatozoa yang sudah matang. Lubang-lubang } \\
\text { permukaan testis dan klasper membesar dan kaku. }\end{array}$ \\
\hline
\end{tabular}

